Alina Miruć

Uniwersytet $w$ Bialymstoku

Ewa Stefańska

Uniwersytet Warszawski

\title{
CHARAKTER PRAWNY I ZASADY SĄDOWEJ KONTROLI DECYZJI PREZESA URZĘDU REGULACJI ENERGETYKI W SPRAWACH ODMOWY PRZYŁACZENIA DO SIECI - NA PRZYKŁADZIE FARM WIATROWYCH
}

\section{Uwagi wstępne}

Po drugiej wojnie światowej w Polsce sektor energetyczny, podobnie jak pozostała część gospodarki, podlegał centralnemu planowaniu. Na rynku funkcjonowały państwowe przedsiębiorstwa energetyczne, które były subsydiowane i sprzedawały energię po cenach kształtowanych poza rynkiem. W 1989 roku Polska wkroczyła w okres reform i transformacji gospodarczej, która doprowadziła do prywatyzacji przedsiębiorstw również $\mathrm{w}$ sektorze energetycznym. ${ }^{1}$ Ponadto, aby osiągnąc rozwój konkurencyjnego rynku energii elektrycznej i umożliwić niedyskryminacyjny dostęp do sieci elektroenergetycznej, konieczne stało się rozdzielenie prowadzonej przez zintegrowane pionowo przedsiębiorstwa energetyczne działalności sieciowej od działalności polegającej na wytwarzaniu i obrocie energią. ${ }^{2}$ Chodziło o oddzielenie sprzedaży energii elektrycznej jako towaru od jej dostawy traktowanej jako usługa, albowiem o ile na rynku energii elektrycznej jako towaru konkurencja między przedsiębiorcami jest możliwa, o tyle jest ona w zasadzie wyłączona na rynku usług dostaw energii, $\mathrm{z}$ uwagi na konieczność posiadania kosztownej infrastruktury przesyłowej (dystrybucyjnej). ${ }^{3}$

\footnotetext{
1 K. Siedlik (ed.), [w:] Energy law in Europe. National, EU and International Regulation, M.M. Roggenkamp, C. Redgwell, I. del Guayo, A. Rønne (ed.), Second edition, Oxford University Press 2007, s. 979-982.

2 K. Smagieł, M. Syroka, Aspekty prawnego wydzielenia działalności operatora systemu dystrybucyjnego, „Biuletyn Urzędu Regulacji Energetyki” 2006, nr 2, s. 44.

3 Szerzej na ten temat m.in.: I. Figaszewska, A. Jasionowicz, Z. Muras, Zasada dostępu stron trzecich do sieci elektroenergetycznej, „Biuletyn Urzędu Regulacji Energetyki” 2001, nr 2, s. 37 oraz K. Kloc-Evison, D. Kośka, [w:] Prawo i ekonomia konkurencji. Wybrane zagadnienia, B. Kurcz (red.), Warszawa 2010, s. 459-461.
} 
Obowiązek uzyskania przez operatorów systemów przesyłowych i systemów dystrybucyjnych niezależności pod względem formy prawnej został sformułowany $\mathrm{w}$ art. $9 \mathrm{~d}$ ustawy - Prawo energetyczne, ${ }^{4} \mathrm{w}$ brzmieniu wynikającym $\mathrm{z}$ art. 1 pkt 16 ustawy z dnia 4 marca 2005 r. o zmianie ustawy - Prawo energetyczne oraz ustawy - Prawo ochrony środowiska. ${ }^{5}$ Nałożenie tego obowiązku było wynikiem implementacji postanowień Dyrektywy 2003/54/WE Parlamentu Europejskiego i Rady z dnia 26 czerwca 2003 r. dotyczącej wspólnych zasad wewnętrznego rynku energii elektrycznej i uchylającej Dyrektywę 96/92/WE. ${ }^{6}$ W Dyrektywie wskazano, że funkcjonowanie konkurencji na rynku energii elektrycznej wymaga, aby dostęp do sieci był niedyskryminacyjny, przejrzysty i uczciwie wyceniony. W celu zapewnienia skutecznego i niedyskryminacyjnego dostępu do sieci za właściwe uznano rozwiązanie, w którym, w przypadku istnienia przedsiębiorstw zintegrowanych pionowo, systemy przesyłowe i dystrybucyjne są prowadzone przez podmioty odrębne prawnie.

$\mathrm{Z}$ art. 10 ust. 1 i art. 15 ust. 1 Dyrektywy 2003/54/WE wynika, że operator systemu przesyłowego (dystrybucyjnego), będący częścią przedsiębiorstwa zintegrowanego pionowo, powinien być niezależny od innych działalności niezwiązanych z przesyłaniem (dystrybucją) przynajmniej co do formy prawnej, organizacji i podejmowania decyzji. W art. 10 ust. 2 i art. 15 ust. 2 Dyrektywy 2003/54/WE zostały określone kryteria minimalne zapewnienia niezależności operatora systemu przesyłowego (dystrybucyjnego), jednakże nie obejmują one obowiązku oddzielenia własności środków w systemie przesyłowym (dystrybucyjnym) od przedsiębiorstwa zintegrowanego pionowo, w szczególności nie jest wymagana zmiana własności aktywów. Przy tym, przedsiębiorstwo zintegrowane pionowo jest definiowane jako przedsiębiorstwo lub grupa przedsiębiorstw, których wzajemne relacje są określone w art. 3 ust. 3 rozporządzenia Rady (EWG) nr 4064/89 z dnia 21 grudnia 1989 r. w sprawie kontroli koncentracji przedsiębiorstw, ${ }^{7}$ gdy dane przedsiębiorstwo (grupa) realizuje co najmniej jedną z funkcji przesyłania lub dystrybucji i co najmniej jedną z funkcji wytwarzania lub dostarczania energii elektrycznej. ${ }^{8}$

Zgodnie z art. 2 Dyrektywy 2003/54/WE „wytwarzanie” oznacza produkcję energii elektrycznej (pkt 1), „przesyłanie” oznacza transport energii elektrycznej przez połączoną sieć bardzo wysokiego i wysokiego napięcia w celu dostawy do odbiorców końcowych lub do dystrybutorów, nie obejmuje natomiast dostaw (pkt 3), zaś „dystrybucja” oznacza transport energii elektrycznej systemami dystrybucyjnymi wysokiego, średniego i niskiego napięcia w celu dostarczania jej do odbior-

Ustawa z dnia 10 kwietnia 1997 r. - Prawo energetyczne (jedn. tekst Dz.U. z 2012 r. poz. 1504), zwana dalej „pr. energ.".

5 Dz.U. Nr 62, poz. 552

$6 \quad$ Dz. Urz. UE L 176 z 15.07 .2003 , s. 211

7 Dz. Urz. UE L 395 z 30.12.1989, s. 1. Rozporządzenie to zostało zmienione rozporządzeniem Rady (WE) nr 1310/97 z dnia 30 czerwca 1997 r. zmieniającym rozporządzenie (EWG) nr 4064/89 w sprawie kontroli koncentracji przedsiębiorstw (Dz. U. L 180 z 09.07.1997, s. 1). 
ców, przy czym również nie obejmując dostaw (pkt 5). „Dostawa” oznacza sprzedaż (łącznie z odsprzedażą) energii elektrycznej odbiorcom (pkt 19). W Dyrektywie podkreślono konieczność zapewnienia jednolitego i niedyskryminacyjnego dostępu do sieci przesyłowych (dystrybucyjnych) wszystkim użytkownikom systemu, a więc obowiązek ten dotyczy także podmiotów zamierzających przyłączyć do sieci farmy wiatrowe.

Problematyka trybu i prawnych przesłanek przyłączenia, a zwłaszcza sądowej kontroli decyzji wydanych w sprawie odmowy przyłączenia do sieci farm wiatrowych, jest szczególnie interesująca z tej przyczyny, że nie była ona dotychczas przedmiotem poszerzonej analizy w piśmiennictwie, przy czym w judykaturze rozstrzygnięto już wiele kwestii ważnych z punktu widzenia praktyki. Jest to problematyka istotna również dlatego, że w Dyrektywie 2001/77/WE Parlamentu Europejskiego i Rady z dnia 27 września 2001 r. w sprawie wspierania produkcji na rynku wewnętrznym energii elektrycznej wytwarzanej ze źródeł odnawialnych ${ }^{9}$ potrzebę wspierania odnawialnych źródeł energii elektrycznej uznano za sprawę priorytetową, wskazując, że wykorzystanie tej energii niesie za sobą pozytywny wpływ na ochronę środowiska i przyczynia się do trwałego rozwoju. Przy tym, zgodnie z art. 2 pkt a powołanej Dyrektywy, pojęcie „odnawialne źródła energii” oznacza odnawialne, niekopalne źródła energii, takie jak: energia wiatru, słoneczna, geotermiczna, falowa, pływów, wodna, biomasy, gazu z odpadów, gazu z zakładów oczyszczania ścieków i biogazów. Energię otrzymaną z odnawialnych źródeł energii określa się jako energię ,zieloną”.

\section{Przesłanki powstania obowiązku przyłączenia do sieci i tryb jego realizacji}

Zgodnie $\mathrm{z}$ art. 7 ust. 1 pr.energ. przedsiębiorstwo energetyczne zajmujące się przesyłaniem lub dystrybucją energii jest obowiązane do zawarcia z podmiotami ubiegającymi się o przyłączenie do sieci - na zasadzie równoprawnego traktowania - umowy o przyłączenie do sieci, jeżeli istnieją techniczne i ekonomiczne warunki przyłączenia, a żądający zawarcia umowy spełnia warunki przyłączenia do sieci i odbioru. W judykaturze jednoznacznie wskazuje się, że przepis ten dotyczy nie tylko odbiorców energii, lecz także jej wytwórców, którzy chcieliby przyłączyć się do sieci przesyłowej (dystrybucyjnej), skoro stanowi on o ,podmiotach ubiegających się o przyłączenie do sieci”, a nie o „odbiorcach ubiegających się o przyłą- 
czenie do sieci". ${ }^{10}$ Analogiczny pogląd wyrażany jest w piśmiennictwie. ${ }^{11}$ Oznacza to, że obowiązek zawarcia przez przedsiębiorstwo przesyłowe lub dystrybucyjne umowy o przyłączenie do sieci elektroenergetycznej może powstać także wówczas, gdy z wnioskiem wystąpił przedsiębiorca ubiegający się o przyłączenie farmy wiatrowej.

Powołany przepis nakłada na przedsiębiorstwa przesyłowe (dystrybucyjne) publicznoprawny obowiązek zawierania z podmiotami ubiegającymi się umów o przyłączenie do sieci, które mają charakter cywilnoprawny. Istnienie tego obowiązku jest przejawem realizacji zasady tzw. Third Party Access. ${ }^{12}$ Jednakże obowiązek ten nie ma bezwzględnego charakteru. Przedsiębiorstwo energetyczne jest obowiązane do zawarcia umowy o przyłączenie do sieci wyłącznie wtedy, gdy łącznie spełnione są dwie przesłanki, tj. istnieją techniczne warunki przyłączenia oraz przyłączenie jest ekonomicznie uzasadnione. ${ }^{13}$ Warunki te mają charakter obiektywny, więc ich istnienie jest niezależne od woli i działań podejmowanych przez potencjalne strony umowy. Natomiast brak warunków technicznych i ekonomicznych przyłączenia jest równoznaczny z nieistnieniem obowiązku zawarcia z przedsiębiorcą ubiegającym się o przyłączenie farmy wiatrowej umowy o przyłączenie do sieci.

Istnienie powyższych przesłanek podlega badaniu przez przedsiębiorstwo przesyłowe (dystrybucyjne), jeżeli wpłynie do niego wniosek podmiotu ubiegającego się o przyłączenie do sieci. Zgodnie z art. 7 ust. 3a i 3b pr.energ. podmiot żądający zawarcia umowy składa wniosek o określenie warunków przyłączenia do sieci $\mathrm{w}$ danym przedsiębiorstwie energetycznym, przy czym wniosek ten powinien zawierać m.in. oznaczenie podmiotu ubiegającego się o przyłączenie oraz informacje niezbędne do zapewnienia spełnienia wymagań technicznych i eksploatacyjnych, o których mowa w art. 7a pr.energ. ${ }^{14}$ Wymagane elementy wniosku składanego przez

Por. m.in. uzasadnienia wyroków SN z dnia 11 kwietnia 2012 r., sygn. akt III SK 33/11, OSNP 2013, nr 9-10, s. 20) oraz Sądu Apelacyjnego w Warszawie z dnia 21 września 2011 r., sygn. akt VI ACa 72/11, niepubl., z dnia 19 stycznia 2012 r., sygn. akt VI ACa 1411/11 (niepubl.), z dnia 26 kwietnia 2012 r., sygn. akt VI ACa 1500/11 (niepubl.), z dnia 25 maja 2012 r., sygn. akt VI ACa 1510/11, niepubl., z dnia 4 czerwca 2012 r., sygn. akt VI ACa 1508/11, niepubl., z dnia 19 lipca 2012 r., sygn. akt VI ACa 387/12, niepubl., z dnia 9 sierpnia 2012 r., sygn. akt VI ACa 419/12, niepubl., z dnia 7 września 2012 r., sygn. akt VI ACa 688/12, niepubl., z dnia 31 stycznia 2013 r., sygn. akt VIACa 895/12, niepubl..

11 M. Nowaczek-Zaremba, D. Nowak, [w:] Prawo energetyczne. Komentarz, M. Swora (red.), Warszawa 2010, s. 518 i powołana tam literatura.

12 Na temat obowiązku zawarcia umowy o przyłączenie do sieci jako realizacji zasady Third Party Access (TPA) szerzej: F. Elżanowski, Polityka energetyczna. Prawne instrumenty realizacji, Warszawa 2008, s. 160-168.

13 A. Walaszek-Pyzioł, W. Pyzioł, Obowiązek zawarcia umowy o przyłączenie do sieci elektroenergetycznej - węzłowe zagadnienia prawne, PUG 2006, nr 12, s. 4.

14 Powyższe wymagania są traktowane jako subiektywna przesłanka merytoryczna zawarcia umowy o przyłączenie do sieci, albowiem ich spełnienie zależy od ubiegającego się o przyłączenie do sieci wytwórcy energii i przedsiębiorstwa energetycznego, M. Nowaczek-Zaremba, D. Nowak, Prawo energetyczne..., op. cit., s. 523-525. Zgodnie z § 4 rozporządzenia Ministra Gospodarki z dnia 4 maja 2007 r. w sprawie szczegółowych warunków funkcjonowania systemu elektroenergetycznego (Dz.U. Nr 93, poz. 623), przyłączenie podmiotu do sieci następuje na podstawie umowy o przyłączenie do sieci i po spełnieniu warunków przyłączenia do sieci (tzw. warunków przyłączenia). Zgodnie z § 5 rozporządzenia, wymagania techniczne w zakresie przyłączania do sieci urządzeń wytwórczych, sieci dystrybucyjnych elektroenergetycznych, urządzeń odbiorców końcowych, połączeń międzysystemowych oraz linii bezpośrednich określa załącznik nr 1 do rozporządzenia. 
wytwórcę energii zostały szczegółowo określone w $\S 7$ pkt 1 i 2 rozporządzenia Ministra Gospodarki w sprawie szczegółowych warunków funkcjonowania systemu elektroenergetycznego, ${ }^{15}$ zaś w $\S 7$ pkt 3 tego rozporządzenia wskazano dodatkowe dane i informacje, które należy podać we wniosku o określenie warunków przyłączenia farm wiatrowych. Wniosek przedsiębiorcy ubiegającego się o przyłączenie farmy wiatrowej powinien wskazywać m.in. liczbę jednostek wytwórczych farmy wiatrowej, typy generatorów, a także przewidywane wartości parametrów elektrycznych sieci i transformatorów wchodzących w skład instalacji i urządzeń farmy wiatrowej. Do wniosku należy dołączyć m.in. dokument potwierdzający tytuł prawny wnioskodawcy do korzystania z obiektu, w którym będą używane przyłączane instalacje lub sieci, wyciąg ze sprawozdania z badań jakości energii elektrycznej wytworzonej przez turbiny wiatrowe, a także ekspertyzę wpływu przyłączanych instalacji lub sieci na system elektroenergetyczny.

Wskutek złożenia wniosku, przedsiębiorstwo energetyczne jest obowiązane do dokonania oceny, czy przyłączenie podmiotu wnioskującego jest możliwe z technicznego punktu widzenia, tj. czy istnieje możliwość przyjmowania do sieci określonej ilości energii elektrycznej, a także czy przyłączenie to jest ekonomicznie uzasadnione. Po dokonaniu niezbędnych ustaleń, przedsiębiorstwo energetyczne: jeżeli stwierdzi istnienie warunków technicznych i ekonomicznych, wydaje warunki przyłączenia, zaś jeżeli stwierdzi ich brak, odmawia zawarcia umowy o przyłączenie do sieci, o czym informuje Prezesa Urzędu Regulacji Energetyki i zainteresowany podmiot, podając przyczyny odmowy (art. 7 ust. 1 in fine pr.energ.). W piśmiennictwie wskazuje się, że procedura powiadomienia organu regulacyjnego ma obecnie wyłącznie charakter informacyjny. ${ }^{16}$ Warunki przyłączenia są przekazywane wnioskodawcy wraz z projektem umowy o przyłączenie do sieci, przy czym są one ważne dwa lata od dnia ich określenia. ${ }^{17}$

W orzecznictwie administracyjnym i sądowym początkowo występowała rozbieżność poglądów co do tego, czy sam fakt wydania przez przedsiębiorstwo przesyłowe (dystrybucyjne) warunków przyłączenia do sieci przesądza o istnieniu materialnoprawnych przesłanek zawarcia z podmiotem ubiegającym się umowy o przyłączenie do sieci, czy też zawarcie takiej umowy uwarunkowane jest uprzednim dokonaniem ustaleń faktycznych, co do istnienia technicznych i ekonomicznych możliwości przyłączenia do sieci instalacji zainteresowanego podmiotu. Ostatecznie w judykaturze przyjęto za trafne drugie z powyższych stanowisk, które zakłada, że fakt wydania przez przedsiębiorstwo energetyczne warunków przyłączenia nie przesądza o istnieniu technicznych i ekonomicznych warunków przyłączenia. Natomiast

\footnotetext{
15 Rozporządzenie Ministra Gospodarki z dnia 4 maja 2007 r. w sprawie szczegółowych warunków funkcjonowania systemu elektroenergetycznego (Dz.U. Nr 93, poz. 623), zwane dalej „rozporządzenie s.w.f.s.e.”. M. Czarnecka, T. Ogłódek, Prawo energetyczne. Komentarz, Warszawa 2009, s. 154-155.

$17 \quad$ Jednakże $z$ art. 7 ust. 1-3 ustawy z dnia 8 stycznia 2010 r. o zmianie ustawy - Prawo energetyczne oraz o zmianie niektórych innych ustaw (Dz.U. Nr 21, poz. 104) wynika, że w przypadku niewniesienia zaliczki w terminie określonym w art. 7 ust. 1 ustawy, warunki przyłączenia tracą ważność.
} 
pierwsze ze stanowisk zostało uznane za wadliwe z tej przyczyny, że z treści $\S 8$ ust. 1 rozporządzenia Ministra Gospodarki z dnia 4 maja 2007 r. w sprawie szczegółowych warunków funkcjonowania systemu elektroenergetycznego jednoznacznie wynika, iż warunki przyłączenia określają tylko kwestie techniczne, ${ }^{18}$ nie odnosząc się w ogóle do przesłanki technicznej możliwości przyłączenia źródła energii i ekonomicznej zasadności koniecznych do tego inwestycji.

Ponadto w orzecznictwie zasadnie wskazuje się, że akceptacja pierwszego z poglądów prowadziłaby do nieuzasadnionego zróżnicowania zakresu ochrony praw przedsiębiorstw energetycznych zarządzających siecią. Jeżeli przedsiębiorstwo od razu odmówiłoby zawarcia umowy powołując się na brak przesłanek materialnoprawnych, Prezes Urzędu Regulacji Energetyki byłby zobligowany do wykazania, że przesłanki te zostały spełnione. Natomiast gdyby przedsiębiorstwo uprzednio określiło, po spełnieniu jakich warunków technicznych i finansowych możliwe jest przyłączenie do sieci nowych wytwórców, w przypadku sporu co do tych warunków i treści umowy, organ regulacyjny nie musiałby w ogóle wykazywać, że publicznoprawny obowiązek zawarcia umowy o przyłączenie do sieci ciążył na tym przedsiębiorstwie, gdyż kwestia ta zostałaby przesądzona przez samo wydanie warunków przyłączenia. ${ }^{19}$

Jeżeli spełnione są materialnoprawne przesłanki określone $\mathrm{w}$ art. 7 ust. 1 pr.energ., przedsiębiorstwo przesyłowe (dystrybucyjne) jest zobligowane do zawarcia $\mathrm{z}$ przedsiębiorcą ubiegającym się o przyłączenie farmy wiatrowej umowy o przyłączenie do sieci. Jest to umowa nazwana, której istotne elementy (essentialia negotii) zostały uregulowane w art. 7 ust. 2 pr.energ. i do której zastosowanie mają przepisy księgi pierwszej i trzeciej Kodeksu cywilnego. ${ }^{20}$ Umowa ta powinna zawierać, co najmniej postanowienia określające: termin realizacji przyłączenia, wysokość opłaty za przyłączenie, miejsce rozgraniczenia własności sieci przedsiębiorstwa energetycznego i instalacji podmiotu przyłączanego, ${ }^{21}$ zakres robót niezbędnych przy realizacji przyłączenia, wymagania dotyczące lokalizacji układu pomiaroworozliczeniowego i jego parametrów, warunki udostępnienia przedsiębiorstwu energetycznemu nieruchomości należącej do podmiotu przyłączanego w celu budowy lub rozbudowy sieci niezbędnej do realizacji przyłączenia, moc przyłączeniową, odpowiedzialność stron za niedotrzymanie warunków umowy, a w szczególności za opóźnienie terminu realizacji prac w stosunku do ustalonego w umowie, oraz okres obowiązywania umowy i warunki jej rozwiązania.

Dodatkowo z art. 7 ust. 9 pr.energ. wynika, że w przypadku, gdy przedsiębiorstwo energetyczne odmówiło przyłączenia do sieci z powodu braku warunków ekonomicznych, może ono zawrzeć umowę o przyłączenie do sieci, ustalając za to opłatę

Dz.U. Nr 93, poz. 623.

Uzasadnienie wyroku SN z dnia 11 kwietnia 2012 r., sygn. akt III SK 33/11, OSNP 2013, nr 9-10, s. 120.

M. Czarnecka, T. Ogłódek, Prawo energetyczne..., op. cit., s. 154.

G. Bieniek, Urządzenia przesyłowe. Problematyka prawna, Warszawa 2008, s. 11 i n. 
w wysokości uzgodnionej z podmiotem zainteresowanym. Ustawodawca nie przewidział analogicznej możliwości w przypadku, gdy przedsiębiorstwo energetyczne odmówiło przyłączenia do sieci wyłącznie z powodu braku warunków technicznych, albowiem warunki techniczne zwykle są pochodną warunków ekonomicznych. W pozostałych przypadkach, gdy istnieją warunki techniczne i ekonomiczne, za przyłączenie do sieci pobiera się opłatę ustaloną zgodnie z zasadami określonymi $\mathrm{w}$ art. 8 pr.energ. Zawarcie $\mathrm{z}$ przedsiębiorcą ubiegającym się o przyłączenie farmy wiatrowej umowy o przyłączenie do sieci otwiera mu możliwość technicznej realizacji przyłączenia, celem umożliwienia korzystania z systemu elektroenergetycznego.

\section{Obowiązek rozbudowy sieci przedsiębiorcy energetycznego}

Z przesłanką istnienia warunków technicznych przyłączenia do sieci wiąże się ściśle nałożony przez ustawodawcę na przedsiębiorstwa przesyłowe (dystrybucyjne) obowiązek rozbudowy sieci. Zgodnie $z$ art. 7 ust. 5 pr.energ. przedsiębiorstwo energetyczne zajmujące się przesyłaniem lub dystrybucją energii jest obowiązane zapewnić realizację i finansowanie budowy i rozbudowy sieci, w tym na potrzeby przyłączania podmiotów ubiegających się o przyłączenie, na warunkach określonych w przepisach wydanych na podstawie art. 9 ust. 1-4, 7 i 8 i art. 46 oraz w założeniach lub planach, o których mowa w art. 19 i 20 pr.energ.

Przepis ten nakłada na przedsiębiorstwa przesyłowe (dystrybucyjne) obowiązek rozbudowy sieci oraz finansowania rozbudowy sieci na potrzeby przyłączania innych podmiotów. Jednakże obowiązek ten nie ma charakteru bezwzględnego i aktualizuje się wyłącznie w zakresie wynikającym z przepisów wykonawczych wydanych na podstawie art. 9 oraz 46 pr.energ. oraz z założeń lub planów, o których mowa w art. 19 i 20 pr.energ. Natomiast brak jest podstaw do wywodzenia tego obowiązku z planu rozwoju przedsiębiorstwa energetycznego, o którym mowa w art. 16 pr.energ., albowiem art. 7 ust. 5 pr.energ. nie odwołuje się w swej treści do tych planów. ${ }^{22}$

$\mathrm{Z}$ wydanego na podstawie art. 9 pr.energ. rozporządzenia s.w.f.s.e. wynika, że przedsiębiorstwo energetyczne zajmujące się przesyłaniem lub dystrybucją energii elektrycznej świadczy usługi przesyłania lub dystrybucji tej energii na warunkach określonych w koncesji, w taryfie, w umowie o świadczenie usług przesyłania lub dystrybucji energii elektrycznej lub w umowie kompleksowej oraz w instrukcji, o której mowa w art. 9g ust. 1 pr.energ. Operator systemu przesyłowego (dystrybucyjnego) jest obowiązany do opracowania instrukcji ruchu i eksploatacji sieci przesyłowej (dystrybucyjnej). Instrukcje opracowywane dla sieci elektroenergetycznych określają szczegółowe warunki korzystania z tych sieci przez użytkowników systemu oraz warunki i sposób prowadzenia ruchu, eksploatacji i planowania rozwoju 
tych sieci, dotyczące m.in. przyłączania urządzeń wytwórczych, wymagań technicznych dla urządzeń, instalacji i sieci wraz z niezbędną infrastrukturą pomocniczą, kryteriów bezpieczeństwa funkcjonowania systemu elektroenergetycznego, wymagań w zakresie bezpieczeństwa pracy sieci elektroenergetycznej. Natomiast w wydanym na podstawie art. 46 pr.energ. rozporządzeniu Ministra Gospodarki z dnia 18 sierpnia 2011 r. w sprawie szczegółowych zasad kształtowania i kalkulacji taryf oraz rozliczeń $\mathrm{w}$ obrocie energią elektryczną ${ }^{23}$ określone zostały szczegółowe zasady kształtowania taryf dla energii elektrycznej, kalkulacji cen i stawek opłat, a także rozliczeń z odbiorcami oraz między przedsiębiorstwami energetycznymi.

Jednakże nie tylko przepis art. 7 ust. 5 pr.energ. nakłada na przedsiębiorstwa energetyczne obowiązek rozbudowy sieci, albowiem w orzecznictwie wskazuje się, że obowiązek rozbudowy sieci wynika również z art. 4 ust. 1 i art. 9c ust. 3 pkt 3 i 4 pr.energ. ${ }^{24}$ Jednakże obowiązek ten nie pozostaje w związku z rozbudową sieci na potrzeby przyłączania nowych podmiotów, lecz ma na celu utrzymanie spójności i prawidłowego działania systemu energetycznego. Jest to, więc obowiązek budowy odpowiednich połączeń między sieciami należącymi do poszczególnych przedsiębiorstw energetycznych i ich modernizacji, także w celu podniesienia poziomu dopuszczalnych obciążeń w związku ze zwiększonym zapotrzebowaniem na moc. $\mathrm{Z}$ przepisów tych nie wynika jednak, aby publicznoprawny obowiązek dbałości o stan sieci przesyłowej i dystrybucyjnej rozciągał się na inwestycje wymuszone przez przyłączanie kolejnych podmiotów. ${ }^{25}$

Dlatego obowiązek rozbudowy przez przedsiębiorstwo energetyczne własnej sieci w związku z przyłączeniem do niej nowej instalacji, w tym farmy wiatrowej, można byłoby oprzeć na art. 4 ust. 1 i art. 9c ust. 3 pkt 3 i 4 pr.energ. wyłącznie wówczas, gdyby spełnione były przesłanki art. 7 ust. 1 pr.energ., zaś konieczność rozbudowy sieci podyktowana była nie tyle przyłączeniem zainteresowanego, lecz koniecznością realizacji obowiązków ciążących na przedsiębiorstwie energetycznym na podstawie art. 4 ust. 1 i art. 9 c ust. 3 pkt 3 i 4 pr.energ.

\section{Decyzje Prezesa URE wydawane w sprawach odmowy przyłączenia do sieci}

$\mathrm{Z}$ art. 8 ust. 1 pr.energ. wynika, że w sprawach spornych dotyczących odmowy zawarcia umowy o przyłączenie do sieci, na wniosek strony, rozstrzyga Prezes Urzędu Regulacji Energetyki. ${ }^{26} \mathrm{~W}$ tym wypadku, organ regulacyjny rozstrzyga spory 
powstałe na tle zawierania umów, których obowiązek zawarcia wynika z ustawy. W piśmiennictwie wskazuje się, że wyłączenie tych spraw, będących sprawami cywilnymi w znaczeniu materialnym, z kognicji sądów powszechnych, było podyktowane zamiarem powierzenia orzekania w nich organowi wyspecjalizowanemu w sprawach energetycznych. ${ }^{27}$ Celem wprowadzenia takiej regulacji było ponadto przyśpieszenie rozpoznawania spraw, a także osiągnięcie jednolitości w orzecznictwie dzięki powierzeniu orzekania jednemu organowi regulacyjnemu. ${ }^{28}$

Kompetencja organu regulacyjnego do wydania decyzji zastępującej umowę o przyłączenie do sieci aktualizuje się w sytuacji, gdy w postępowaniu administracyjnym zostanie wykazane, że pomimo odmowy zawarcia umowy o przyłączenie do sieci przez przedsiębiorstwo przesyłowe (dystrybucyjne), istniały warunki techniczne i ekonomiczne przyłączenia. Także w sytuacji, jeżeli podmiot zainteresowany przyłączeniem do sieci kwestionuje warunki zaoferowanego mu przez przedsiębiorstwo przesyłowe (dystrybucyjne) projektu umowy o przyłączenie do sieci i występuje do Prezesa Urzędu Regulacji Energetyki z wnioskiem o rozstrzygnięcia sporu, organ regulacyjny zobowiązany jest najpierw ustalić, czy na przedsiębiorstwie energetycznym spoczywał obowiązek zawarcia umowy zgodnie z art. 7 ust. 1 pr.energ., a następnie ocenić, które z postanowień projektu umowy wymagają zmiany. Natomiast Prezes Urzędu Regulacji Energetyki nie może na podstawie art. 8 ust. 1 pr.energ. orzekać w sprawach dotyczących umów już zawartych. ${ }^{29}$

W orzecznictwie wskazuje się, że art. 8 ust. 1 pr.energ. w odniesieniu do określonej $\mathrm{w}$ nim kompetencji organu regulacyjnego dotyczącej rozstrzygnięcia sporu zobowiązaniowego (cywilnoprawnego) jest samoistnym źródłem prawa, co eliminuje potrzebę sięgania do konstrukcji cywilistycznych (art. 64 k.c.). Decyzja Prezesa Urzędu Regulacji Energetyki zastępuje oświadczenia woli stron w znaczeniu funkcjonalnym, zaś sama decyzja stanowi podstawę samoistnego ukształtowania stosunku zobowiązaniowego w zakresie spraw spornych między stronami. ${ }^{30}$ Przy tym, jeżeli przedmiotem postępowania jest ustalenie treści umowy o przyłączenie do sieci przedsiębiorstwa energetycznego, wydana w trybie art. 8 ust. 1 pr.energ. decyzja Prezesa Urzędu Regulacji Energetyki powinna orzec o zawarciu umowy, jeżeli żądający zawarcia umowy spełnia warunki przyłączenia do sieci. Natomiast wadliwa jest decyzja ograniczająca się do stwierdzenia po stronie przedsiębiorstwa energetycznego obowiązku przyłączenia do sieci energetycznej nieruchomości odbiorcy, przy uwzględnieniu postanowień taryfy i przepisów wykonawczych do ustawy. ${ }^{31}$

\footnotetext{
27 M. Czarnecka, T. Ogłódek, Prawo energetyczne..., op. cit., s. 173-175.

28 J. Baher, E. Stawicki, Prawo energetyczne. Komentarz, Warszawa 1999, s. 55

29 Uzasadnienie wyroku Sądu Najwyższego z dnia 7 października 2004 r., sygn. akt III SK 56/04, OSNP 2005, nr 12, s. 181.

30 Uzasadnienie wyroku SN z dnia 12 kwietnia 2011 r., sygn. akt III SK 42/10, Lex nr 89842.

31 Uzasadnienie wyroku Sądu Antymonopolowego z dnia 21 lipca 1999 r., sygn. akt XVII Ame 24/99, „Wokanda” 2000, nr 11, poz. 56.
} 
W judykaturze trafnie wskazuje się, że przepis art. 7 ust. 1 pr.energ. nie daje potencjalnemu kontrahentowi przedsiębiorstwa energetycznego roszczenia o zawarcie umowy, tak jak to ma miejsce $\mathrm{w}$ odniesieniu do roszczenia o zawarcie umowy przyrzeczonej (art. 390 § 2 k.c.). Nie przysługuje mu, bowiem prawo do wiążącego dla przedsiębiorcy energetycznego określenia istotnych postanowień umowy, której zawarcia się domaga. Na przedsiębiorstwie energetycznym spoczywa natomiast publicznoprawny obowiązek zawarcia umowy, co oznacza, że przedsiębiorstwo to nie może bez uzasadnionego powodu odmówić zawarcia umowy, zachowując jednakże prawo do negocjowania jej treści. Kompetencje orzecznicze Prezesa Urzędu Regulacji Energetyki, o których mowa w art. 8 ust. 1 pr.energ., obejmują zarówno zawieranie umów, jak i ustalanie ich treści. ${ }^{32}$

Stronami postępowania przed Prezesem Urzędu Regulacji Energetyki są wnioskujący o rozstrzygnięcie sporu przedsiębiorca ubiegający się o przyłączenie farmy wiatrowej oraz przedsiębiorstwo przesyłowe (dystrybucyjne), które odmówiło zawarcia umowy o przyłączenie do sieci. Są to podmioty, które spełniają określone w art. 28 Kodeksu postępowania administracyjnego ${ }^{33}$ kryteria bycia stroną, gdyż ich interesu prawnego lub obowiązku dotyczy postępowanie. Zgodnie z art. 8 ust. 1 pr.energ. postępowanie administracyjne jest wszczynane na wniosek, a więc na żądanie strony w rozumieniu art. $61 \S 1$ k.p.a. Przy tym, w piśmiennictwie wyrażany jest pogląd, że zgłaszane w tym wypadku żądanie strony wszczęcia postępowania administracyjnego jest zbliżone charakterem do sądowego powództwa o ustalenie (ukształtowanie) stosunku prawnego. ${ }^{34}$ Rozstrzyganie sporów, o których mowa $\mathrm{w}$ art. 8 ust. 1 pr.energ., następuje w trybie postępowania administracyjnego określonego przepisami k.p.a., co wynika $\mathrm{z}$ art. 3 ust. 1 pr.energ. ${ }^{35}$

\section{Tryb i zasady sądowej kontroli decyzji Prezesa URE}

Zgodnie $\mathrm{z}$ art. $479^{46}$ Kodeksu postępowania cywilnego, ${ }^{36} \mathrm{w}$ sprawach odwołań od decyzji Prezesa Urzędu Regulacji Energetyki właściwy jest Sąd Okręgowy w Warszawie - sąd ochrony konkurencji i konsumentów. Z art. 30 ust. 2 i 3 pr.energ. wynika, że od decyzji Prezesa Urzędu Regulacji Energetyki służy odwołanie $\mathrm{w}$ terminie dwutygodniowym od dnia doręczenia decyzji, przy czym postępowanie w sprawie tego odwołania toczy się według przepisów k.p.c. o postępowaniu w sprawach z zakresu regulacji energetyki (art. $479^{46}-479^{56}$ k.p.c.). Z kolei art. $479^{47}$

Uzasadnienie wyroku Sądu Antymonopolowego z dnia 7 kwietnia 1999 r., sygn. akt XVII Ama 85/98, Lex nr 55917.

Ustawa z dnia 14 czerwca 1960 r. - Kodeks postępowania administracyjnego (t.j. Dz.U. z 2013 r., poz. 267), zwana dalej „k.p.a.”.

S. Gronowski, Prawo energetyczne. Wprowadzenie. Przepisy wykonawcze, Warszawa 1999, s. 20.

M. Pawełczyk (red.), Prawo energetyczne. Komentarz, Poznań 2012, s. 216.

Ustawa z dnia 17 listopada 1964 r. - Kodeks postępowania cywilnego (Dz.U. Nr 43, poz. 296 z póżn.zm..), zwana dalej „k.p.c.”. 
$\S 1$ k.p.c. stanowi, że odwołanie od decyzji Prezesa Urzędu Regulacji Energetyki wnosi się do sądu za jego pośrednictwem. Rozwiązanie to pozwala na zastosowanie przez organ regulacyjny trybu autokontroli. $Z$ art. $379^{48} \S 2$ k.p.c. wynika bowiem, że jeżeli Prezes Urzędu Regulacji Energetyki uzna odwołanie za słuszne, może - nie przekazując akt sądowi - uchylić albo zmienić swoją decyzję w całości lub w części, o czym bezzwłocznie powiadamia stronę, przesyłając jej nową decyzję, od której stronie służy odwołanie.

Zgodnie z art. $479^{49}$ k.p.c. odwołanie od decyzji Prezesa Urzędu Regulacji Energetyki powinno czynić zadość wymaganiom przepisanym dla pisma procesowego oraz zawierać oznaczenie zaskarżonej decyzji, przytoczenie zarzutów, zwięzłe ich uzasadnienie, wskazanie dowodów, a także zawierać wniosek o uchylenie lub zmianę decyzji w całości lub w części. Ponieważ odwołanie uruchamia postępowanie sądowe w pierwszej instancji, powinno ono spełniać warunki formalne pozwu. Powołany przepis nie wprowadza ustawowej prekluzji twierdzeń (zarzutów) i dowodów, jeżeli nie zostały one zgłoszone w odwołaniu. Również Prezes Urzędu Regulacji Energetyki nie ma obowiązku wniesienia w określonym ustawowo terminie odpowiedzi na odwołanie zawierającej wszystkie twierdzenia, zarzuty oraz dowody na ich poparcie, pod rygorem utraty prawa ich powoływania w dalszym toku postępowania. ${ }^{37}$ Zasady koncentracji materiału dowodowego w sprawach z zakresu regulacji energetyki regulują obecnie art. $207 \mathrm{i}$ art. 217 k.p.c. W sprawach tych obowiązują także przepisy dotyczące ciężaru dowodu (art. 6 k.c. i art. 232). ${ }^{38}$

Rozpoznając odwołanie, sąd ochrony konkurencji i konsumentów zobowiązany jest do dokonania merytorycznej oceny zasadności twierdzeń i żądań zawartych w odwołaniu w świetle obowiązujących przepisów prawa materialnego, a nie do badania formalnej poprawności decyzji. ${ }^{39} \mathrm{~W}$ judykaturze wskazuje się, że sąd ochrony konkurencji i konsumentów jest związany zakresem zaskarżenia decyzji, lecz nie sformułowanymi w odwołaniu wnioskami. Przyjęcie odmiennego stanowiska prowadziłoby, bowiem do uznania, że funkcja sądu ochrony konkurencji i konsumentów ograniczona jest do roli akceptanta woli jednej ze stron, przy braku możliwości merytorycznego rozstrzygnięcia sprawy stosownie do wyników przeprowadzonego postępowania dowodowego. ${ }^{40}$

37 Jednakże w sprawach, w których decyzje Prezesa Urzędu Regulacji Energetyki zostały wydane przed dniem 3 maja 2012 r., w postępowaniu w sprawach z zakresu regulacji energetyki w kwestiach nieuregulowanych w przepisach szczególnych, nadal należy stosować uchylone przepisy dotyczące postępowania w sprawach gospodarczych. W tych sprawach obowiązuje ustawowa prekluzja w zakresie twierdzeń i wniosków dowodowych, odnosząca się do obydwu stron procesu - zob. uzasadnienie wyroku Sądu Najwyższego z dnia 2 kwietnia 2009 r., sygn. akt III SK 30/08, OSNP 2010, nr 21-22, poz. 278.

38 E. Stefańska, [w:] Kodeks postępowania cywilnego. Komentarz, M. Manowska (red.), tom 1 (art. 1-50537), Warszawa 2011, s. 1077-1078.

39 Uzasadnienie wyroku Sądu Apelacyjnego w Warszawie z dnia 24 marca 2010 r., sygn. akt VI ACa 1088/09, LexisNexis nr 2229837.

40 Zob. uzasadnienie wyroku Sądu Ochrony Konkurencji i Konsumentów z dnia 26 stycznia 2010 r., sygn. akt XVII Ama 62/09, LexisNexis nr 2563225. 
W orzecznictwie podkreśla się, że dopiero zamknięcie postępowania administracyjnego zakończonego wydaniem decyzji powoduje, że sprawa dotychczas administracyjna ( $\mathrm{w}$ tym wypadku w ujęciu tylko formalnym) z chwilą wniesienia odwołania staje się sprawą cywilną $\mathrm{w}$ rozumieniu art. 1, rozpoznawaną zgodnie z przepisami postępowania cywilnego. Dopiero wniesienie odwołania powoduje wszczęcie kontradyktoryjnego postępowania sądowego, bowiem poprzedzające je postępowanie administracyjne warunkuje jedynie dopuszczalność drogi sądowej. ${ }^{41}$ Skoro, więc odwołanie wszczyna dopiero kontradyktoryjne postępowanie cywilne, zadaniem sądu ochrony konkurencji i konsumentów jest osądzenie sprawy od początku. Charakter postępowania administracyjnego wyklucza możliwość oparcia wyroku na ustaleniach organu administracji, więc sąd ochrony konkurencji i konsumentów powinien, po rozważeniu całokształtu materiału dowodowego, dokonać własnych ustaleń faktycznych, powołując dowody, na których się oparł i omawiając dowody przeciwstawne. ${ }^{42}$

$\mathrm{Z}$ art. $479^{50}$ k.p.c. wynika, że w sprawach z zakresu regulacji energetyki stronami są powód (podmiot, który wniósł odwołanie od decyzji), a także Prezes Urzędu Regulacji Energetyki (jako pozwany) oraz zainteresowany. Przy tym, zainteresowanym jest ten, czyje prawa lub obowiązki zależą od rozstrzygnięcia procesu ${ }^{43} \mathrm{~W}$ sprawach spornych dotyczących odmowy zawarcia umowy o przyłączenie do sieci organ regulacyjny może wydać decyzję orzekającą zawarcie umowy o określonej treści, bądź decyzję stwierdzającą, że na przedsiębiorstwie energetycznym nie ciąży obowiązek zawarcia umowy o przyłączenie do sieci z przedsiębiorcą ubiegającym się o przyłączenie farmy wiatrowej. Powodem jest zawsze ten podmiot, który jest niezadowolony $\mathrm{z}$ treści decyzji (zarówno, co do istnienia obowiązku zawarcia umowy, jak i co do jej treści) i wnosi odwołanie, dlatego może nim być zarówno przedsiębiorstwo przesyłowe (dystrybucyjne), jak i przedsiębiorca ubiegający się o przyłączenie farmy wiatrowej. Natomiast podmiot, który był stroną postępowania administracyjnego i nie wniósł odwołania, w procesie cywilnym ma status zainteresowanego.

Jeżeli nie ma podstaw do wydania orzeczenia o charakterze formalnym (odrzucenie odwołania, umorzenie postępowania), sąd ochrony konkurencji i konsumentów rozpoznaje sprawę merytorycznie i wydaje wyrok. Katalog dopuszczalnych rozstrzygnięć merytorycznych został określony przez ustawodawcę w art. $479^{53}$ k.p.c. Sąd ochrony konkurencji i konsumentów oddala odwołanie od decyzji Prezesa Urzędu Regulacji Energetyki, jeżeli nie ma podstaw do jego uwzględnienia. Natomiast $\mathrm{w}$ razie uwzględnienia odwołania sąd ochrony konkurencji i konsumentów zaskarżoną decyzję albo uchyla, albo zmienia w całości lub w części i orzeka,

\footnotetext{
41 Uzasadnienie wyroku Sądu Apelacyjnego w Warszawie z dnia 18 lipca 2008 r., sygn. akt VI ACa 91/08, niepubl..

42 Uzasadnienia wyroków SN z dnia 24 października 2002 r., sygn. akt I CKN 1465/00 (LexisNexis nr 375472) i z dnia 19 sierpnia 2009 r., sygn. akt III SK 5/09, OSNP 2011, nr 9-10, poz. 144).

43 Szerzej na temat pozycji prawnej zainteresowanego pisze K. Weitz, [w:] T. Wiśniewski (red.), Postępowanie sądowe w sprawach gospodarczych, System Prawa Handlowego, tom 7, Warszawa 2007, s. 167-168.
} 
co do istoty sprawy. ${ }^{44}$ Pomimo że postępowanie przed sądem ochrony konkurencji i konsumentów jest postępowaniem w pierwszej instancji, jego rozstrzygnięcia są charakterystyczne dla sądu odwoławczego, gdyż nawiązują do zaskarżonej decyzji i wniesionego od niej odwołania. W literaturze dominuje pogląd, że ponieważ postępowanie przed sądem ochrony konkurencji i konsumentów jest prowadzone na podstawie przepisów o postępowaniu przed sądem pierwszej instancji, nie ma do niego zastosowania zakaz reformationis in peius.

W orzecznictwie wskazuje się, że przepisy zezwalają sądowi ochrony konkurencji i konsumentów na to, aby wydał nową decyzję, wchodząc niejako w miejsce Prezesa Urzędu Regulacji Energetyki. Oznacza to, że sąd ochrony konkurencji i konsumentów nie powinien ograniczać się do wskazywania na wadliwości decyzji, lecz władny jest, jeżeli tylko znajdzie to uzasadnienie w okolicznościach sprawy i zebranym materiale faktycznym i dowodowym, usunąć wady tej decyzji. ${ }^{45} \mathrm{Zgod}-$ nie $\mathrm{z}$ art. $479^{56}$ k.p.c., w sprawach z zakresu regulacji energetyki skarga kasacyjna od orzeczenia sądu drugiej instancji przysługuje niezależnie od wartości przedmiotu zaskarżenia.

\section{Podsumowanie}

Przyjęty przez ustawodawcę w Polsce model rozstrzygania sporów o zawarcie umowy o przyłączenie do sieci, toczących się między przedsiębiorcami ubiegającymi się o przyłączenie farmy wiatrowej oraz przedsiębiorstwami przesyłowymi (dystrybucyjnymi), należy ocenić pozytywnie. W pierwszej fazie spór ten jest rozstrzygany przez organ regulacyjny $\mathrm{w}$ toku postępowania administracyjnego, co gwarantuje fachowość podmiotu rozpoznającego sprawę, szybkość postępowania i jednolitość orzecznictwa. Etap ten kończy się wydaniem przez Prezesa Urzędu Regulacji Energetyki decyzji administracyjnej rozstrzygającej spór o charakterze cywilnoprawnym. Przedmiotem tego sporu jest przede wszystkim ustalenie, czy zostały spełnione przesłanki materialnoprawne będące podstawą istnienia po stronie przedsiębiorstwa przesyłowego (dystrybucyjnego) publicznoprawnego obowiązku zawarcia umowy o podłączenie do sieci, a jeżeli tak, to, jakiej treści umowa powinna zostać zawarta. W zależności od poczynionych ustaleń, Prezes Urzędu Regulacji Energetyki może wydać decyzję stwierdzającą, że na przedsiębiorstwie energetycznym nie ciąży obowiązek zawarcia umowy o przyłączenie do sieci, bądź decyzję o określonej treści orzekającą zawarcie umowy o przyłączenie do sieci.

W obydwu tych przypadkach strony postępowania mogą negować prawidłowość decyzji, przy czym gravamen w kwestionowaniu decyzji stwierdzającej brak

\footnotetext{
44 Szarzej na temat rozstrzygnięć sądu G. Jędrejek, [w:] Kodeks postępowania cywilnego. Komentarz, H. Dolecki, T. Wiśniewski (red.), tom II, Warszawa 2010, s. 669.

45 Z uzasadnienia wyroku SN z dnia 29 maja 1991 r., sygn. akt III CRN 120/91, OSNC 1992, nr 5, poz. 87.
} 
obowiązku zawarcia umowy o przyłączenie do sieci ma wyłącznie przedsiębiorca ubiegający się o przyłączenie farmy wiatrowej, natomiast decyzję orzekającą zawarcie umowy o przyłączenie do sieci mogą kwestionować obydwie strony, domagając się zmiany jej konkretnych postanowień. Gdy przynajmniej jedna ze stron sporu jest niezadowolona $\mathrm{z}$ treści rozstrzygnięcia zawartego $\mathrm{w}$ decyzji administracyjnej, może wnieść odwołanie do sądu powszechnego, powodując rozpoczęcie drugiej fazy postępowania. Sąd ochrony konkurencji i konsumentów rozpoznaje sprawę od początku, prowadząc postępowanie dowodowe z zachowaniem zasad kontradyktoryjności i rozkładu ciężaru dowodu, a następnie wydaje wyrok, w którym może oddalić odwołanie, (co skutkuje, że zaskarżona decyzja utrzymuje moc), zmienić decyzję w całości lub części, (gdy uzna, że należy jej nadać inną treść), bądź uchylić decyzję, (gdy uzna, że decyzja nie powinna zostać wydana i powinna zostać wyeliminowana $\mathrm{z}$ obrotu prawnego). Wydanie wyroku zmieniającego treść decyzji jest dopuszczalne wówczas, gdy odwołanie dotyczy decyzji orzekającej zawarcie umowy o przyłączenie do sieci, której poszczególne postanowienia zostały zakwestionowane. Także w wypadku, gdy odwołanie dotyczy decyzji stwierdzającej brak obowiązku zawarcia umowy o przyłączenie do sieci, zaś w ocenie sądu obowiązek ten istnieje, dopuszczalne jest wydanie wyroku zmieniającego treść decyzji w ten sposób, że kształtującego treść umowy o przyłączenie do sieci.

Również przekazanie przez ustawodawcę rozpoznawania odwołań od decyzji Prezesa Urzędu Regulacji Energetyki w sprawach sporów o zawarcie umowy o przyłączenie do sieci, zasługuje na aprobatę. Postępowanie przez sądem ochrony konkurencji i konsumentów, będącym sądem powszechnym, jest szybsze i efektywniejsze od postępowania sądowo administracyjnego.$^{46} \mathrm{O}$ ile, bowiem sąd administracyjny ogranicza się do oceny legalności zaskarżonej decyzji i jest wyposażony w uprawnienia o charakterze kasacyjnym, o tyle sąd powszechny bada merytorycznie sprawę rozstrzygniętą w zaskarżonej decyzji i jest uprawniony do jej samodzielnego rozstrzygnięcia poprzez orzeczenie o zmianie decyzji. Ponadto cywilnoprawny charakter spraw spornych o przyłączenie do sieci przemawia za celowością poddania ich kognicji sądów powszechnych, gdzie gwarancją ich wnikliwego rozpoznania jest dwuinstancyjny system postępowania, uzupełniony możliwością wniesienia nadzwyczajnego środka prawnego w postaci skargi kasacyjnej.

\section{BIBLIOGRAFIA}

Baher J., Stawicki E., Prawo energetyczne. Komentarz, Warszawa 1999.

Bieniek G., Urządzenia przesyłowe. Problematyka prawna, Warszawa 2008. 
Czarnecka M., Ogródek T., Prawo energetyczne. Komentarz, Warszawa 2009.

Elżanowski F., Polityka energetyczna. Prawne instrumenty realizacji, Warszawa 2008.

Figaszewska I., Jasionowicz A., Muras Z., Zasada dostępu stron trzecich do sieci elektroenergetycznej, „Biuletyn Urzędu Regulacji Energetyki” 2001, nr 2.

Gronowski S., Prawo energetyczne. Wprowadzenie. Przepisy wykonawcze, Warszawa 1999.

Jaroszyński K., Wierzbowski M. Podmioty administrujące, [w:] System Prawa Administracyjnego R. Hauser, Z. Niewiadomski, A. Wróbel (red.), t. 6, Warszawa 2011.

Jaśkowska M., Aktualne problemy rozgraniczenia właściwości sądów administracyjnych i powszechnych, Warszawa 2011.

Jędrejek G., [w:] Kodeks postępowania cywilnego. Komentarz, H. Dolecki, T. Wiśniewski (red.), tom II, Warszawa 2010.

Kloc-Evison K., Kośka D., [w:] Prawo i ekonomia konkurencji. Wybrane zagadnienia, B. Kurcz (red.), Warszawa 2010.

Nowaczek-Zaremba M., Nowak D., [w:] Prawo energetyczne. Komentarz, M. Swora (red.), Warszawa 2010 .

Pawełczyk M. (red.), Prawo energetyczne. Komentarz, Poznań 2012.

Siedlik K. (ed.), [w:] Energy law in Europe. National, EU and International Regulation, M.M. Roggenkamp, C. Redgwell, I. del Guayo, A. Rønne (ed.), Second edition, Oxford University Press 2007.

Smagieł K., Sroka M., Aspekty prawnego wydzielenia działalności operatora systemu dystrybucyjnego, „Biuletyn Urzędu Regulacji Energetyki” 2006, nr 2.

Stefańska E., [w:] Kodeks postępowania cywilnego. Komentarz, M. Manowska (red.), tom 1 (art. 1-50537), Warszawa 2011.

Walaszek-Pyzioł A., Pyzioł W., Obowiązek zawarcia umowy o przyłączenie do sieci elektroenergetycznej - węzłowe zagadnienia prawne, PUG 2006, nr 12.

Weitz K., Postępowanie sądowe w sprawach gospodarczych, [w:] System Prawa Handlowego, T. Wiśniewski (red.), tom 7, Warszawa 2007. 


\section{THE LEGAL NATURE AND THE PRINCIPLES OF JUDICIAL REVIEW OF THE PRESIDENT OF THE ENERGY REGULATORY OFFICE DECISIONS' IN THE REFUSAL TO CONNECT TO THE NETWORK CASES - USING WIND FARMS AS AN EXAMPLE}

The model adopted in the polish legal system for dispute settlement in 'connection to the network' contract cases, implies that in the first instance the dispute is settled by the regulatory authority in administrative proceeding. That ensures the competence of the body hearing the case, efficiency of the proceeding and the uniformity of decisions. This phase ends with the President of the Energy Regulatory Office issuing an administrative decision that resolves the civil law dispute. All parties to the proceeding may deny the correctness of the decision. But to litigate the decision establishing lack of obligation to enter into the connection to the network agreement is an entitlement only available to an entrepreneur applying for the connection of a wind farm. An appeal to the common court initiates the second phase of the proceeding. The Court of Competition and Consumer Protection hears the case from the beginning and evaluates the evidence following the rules of adversarial procedure and burden of proof. The proceeding at the common court is faster and more efficient than the proceeding at the administrative court. The administrative court reviews only the legality of the contested decision and is empowered only to revoke it but the common court is entitled to review the case on its merits and is empowered to change the decision. Besides this, connection to the network contract cases are civil cases so it follows that they should be the subject of the common courts cognition. The guarantee of insightful investigation in these cases is the double instances system of proceeding and the availability to file a cassation appeal.

Keywords: connection to the network agreement, wind farm, regulatory authority, administrative proceeding, judicial review 